\title{
28 Research Square \\ THOTTIP is Associated with Prognosis of Lung Cancer in the Chinese Population
}

Yue Zhao ( $\nabla$ dfgwrf@126.com )

Cangzhou Central Hospital https://orcid.org/0000-0002-6847-2261

Xiangjun Kong

Cangzhou Central Hospital

Hongbing Wang

Cangzhou Central Hospital

Research

Keywords: HOTTIP, Prognosis, Lung cancer

Posted Date: August 14th, 2020

DOl: https://doi.org/10.21203/rs.3.rs-57381/v1

License: (1) This work is licensed under a Creative Commons Attribution 4.0 International License.

Read Full License 


\section{Abstract}

Background: Lung cancer is a prevent malignancy with high mortality. Long noncoding RNAs (IncRNAs) have been reported to play important roles in tumorigenesis. The purpose of this study was to explore the prognostic value of IncRNA HOTTIP in lung cancer.

Methods: The expression of HOTTIP in lung cancer tissues was measured by quantitative real-time PCR (qRT-PCR). Chi-square test was applied to assess the correlation of HOTTIP with clinicopathological features. Overall survival curve was built by Kaplan-Meier method with log rank test. Cox regression analysis was used to explore the prognostic value of HOTTIP in lung cancer.

Results: The expression of HOTTIP was significantly increased in lung cancer samples compared with paired noncancerous samples $(P<0.001)$. Moreover, its expression patterns were correlated with lymph node metastasis $(P=0.039)$ and TNM stage $(P=0.007)$. Survival curve demonstrated that lung cancer patients with high level of HOTTIP had poor survival rate (log-rank $P=0.011)$. HOTTIP might be an independent prognostic factor for lung cancer $(\mathrm{HR}=1.916,95 \% \mathrm{Cl}=1.133-3.238, P=0.015)$.

Conclusions: HOTTIP is up-regulated in lung cancer, and associated with aggressive tumor progression. HOTTIP may be a potential prognostic biomarker for lung cancer.

\section{Background}

Lung cancer is one of the most serious health problem worldwide. It is one of the leading cause of cancer related deaths around the world [1]. Unfortunately, evidences reveal that the incidence and mortality of lung cancer have been on the rise [2]. Based on the pathological characteristics, lung cancer can be classified into two types: non-small-cell lung cancer (NSCLC) and small-cell lung cancer (SCLC). NSCLC accounts the major lung cancer cases $[3,4]$. So far, there are some effective therapeutic strategies for patients suffering from lung cancer, such as surgical strategy, chemotherapy and radiotherapy, but the 5year survival rate of lung cancer still remains unsatisfactory $[5,6]$. Early relapse and metastasis are the major reasons for poor prognosis [7]. Thus, identification of novel biomarkers to predict tumor progression may be a promising approach to improve treatment of lung cancer.

Long noncoding RNAs (IncRNAs) are a class of noncoding RNA transcripts with exceed $200 \mathrm{nt}$ in length $[8,9]$. Up to now, there are thousands of IncRNAs have been discovered in human genome. Growing evidences suggest that IncRNAs play important roles in regulation of gene transcription and translation, cell growth, development, differentiation and death $[10,11]$. Aberrant expression of specific IncRNAs has also been proved to be involved in development and progression of human cancers, such as hepatocellular carcinoma, gastric cancer and lung cancer [12-14]. LncRNAs may play pivotal roles in development and progression of lung cancer that can provide a new insight to the pathogenesis of the cancer [15]. 
HOXA transcript at the distal tip (HOTTIP) gene, located on in the 7p15.2 gene desert region, is a newly identified IncRNA [16]. Up-regulation of HOTTIP was observed in various malignancies, including prostate cancer, gastric cancer, and colorectal cancer [17-19]. The over-expression of HOTTIP could promote aggressive development and progression of tumors, suggesting its was an oncogene in malignancy. The oncogenic action of HOTTIP in lung cancer was also reported. Deng and colleagues reported that HOTTIP could regulate proliferation and apoptosis of lung cancer cells, thus contributing to tumor growth [20]. However, the prognostic value of HOTTIP in lung cancer remained unclear.

In this study, we aimed to investigate the prognostic performance of HOTTIP in lung cancer. The expression profiles of HOTTIP in lung cancer tissues were detected, as well as its association with clinical characteristics. In addition, we estimated the effects of HOTTIP expression on overall survival and prognosis of lung cancer patients.

\section{Methods}

Patients and specimens collection

The protocols and clinical materials used in our study were all approved by the ethics committee of Cangzhou Central Hospital. The written informed consent were obtained from all the patients before the surgery.

In the present study, we recruited 132 lung cancer patients, who were diagnosed in Cangzhou Central Hospital. 132 pairs lung cancer tissue and noncancerous samples were collected from the patients and immediately stored in liquid nitrogen at $-80^{\circ} \mathrm{C}$ for further use. All the patients were followed up by telephone call rang from 6 months to 60 months. The clinicopathological characteristics of lung cancer patients, including age, gender, tumor size, differentiation, histology, lymph node metastasis and TNM stage, were recorded in the present study and summarized in Table 1. 
Table 1

Association of HOTTIP with the clinicopathological data of lung cancer patients

\begin{tabular}{|c|c|c|c|c|c|}
\hline \multirow[t]{2}{*}{ Features } & & \multirow{2}{*}{$\begin{array}{l}\text { No. } \\
n=132\end{array}$} & \multicolumn{2}{|c|}{ HOTTIP expression } & \multirow[t]{2}{*}{$P$ values } \\
\hline & & & High $(n=72)$ & $\operatorname{Low}(n=60)$ & \\
\hline Age (years) & & & & & 0.697 \\
\hline$\leq 60$ & & 53 & 30 & 23 & \\
\hline$>60$ & & 79 & 42 & 37 & \\
\hline Gender & & & & & 0.898 \\
\hline Male & & 74 & 40 & 34 & \\
\hline Female & & 58 & 32 & 26 & \\
\hline Tumor size $(\mathrm{cm})$ & & & & & 0.823 \\
\hline$\leq 3$ & & 58 & 31 & 27 & \\
\hline$>3$ & & 74 & 41 & 33 & \\
\hline Differentiation & & & & & 0.921 \\
\hline Well; Moderate & & 49 & 27 & 22 & \\
\hline Poor & & 83 & 45 & 38 & \\
\hline Histology & & & & & 0.841 \\
\hline Adenocarcinoma & 87 & 48 & 39 & & \\
\hline Squamous cell carcinoma & 45 & 24 & 21 & & \\
\hline Lymph node metastasis & & & & 0.039 & \\
\hline Positive & 68 & 43 & 25 & & \\
\hline Negative & 64 & 29 & 35 & & \\
\hline TNM stage & & & & 0.007 & \\
\hline HII & 71 & 31 & 40 & & \\
\hline III-IV & 61 & 41 & 20 & & \\
\hline
\end{tabular}

RNA extraction and quantitative real-time polymerase chain reaction (qRT-PCR)

Total RNAs were extracted from tissue samples with TRIzol reagent (Incitrogen, Carlsbad, CA, USA). The purity and concentration of RNA were calculated with the NanoDrop ND-1000 spectrophotometer (NanoDrop, DE, USA). Only the RNA with OD A260/A280 ratio close 2.0 was used in the further experiments. 
We applied qRT-PCR to examine the expression level of HOTTIP in both lung cancer samples and noncancerous samples. The cDNA was obtained by RNA revers transcription with the AMV reverse transcription system (Promega, USA). QRT-PCR reaction was performed with the SYBR Green PCR master mix (Applied Biosystems, USA) on 7300 Real-Time PCR System (Applied Biosystems, USA). GAPDH gene was employed as endogenous control in this reaction. All the primers were as follows: HOTTIP forward: 5'-CACACTCACATTCGCACACT-3', reverse: 5'-TCCAGAACTAAGCCAGCCATA-3'; GAPDH forward: 5'GTCAACGGATTTGGTCTGTATT-3', reverse: 5'-AGTCTTCTGGGTGGCAGTGAT-3'. The expression level of HOTTIP was calculated with the method of $2^{-\triangle \triangle \mathrm{Ct}}$ and normalized by expression of GAPDH.

\section{Statistical analysis}

The data were expressed as mean \pm SD. The different expression of HOTTIP between lung cancer tissue and paired noncancerous samples was analyzed by Student's $t$ test. To examine the relationship between HOTTIP and the clinicopathological data of lung cancer patients, Chi-square test was applied in our study. Overall survival curves were constructed with Kaplan-Meier method with log rank test. In order to investigate the prognostic accuracy of HOTTIP expression in lung cancer patients, cox regression analysis was carried out. Only the results with $P$ value of $<0.05$ were considered statistically significant. All statistical analyses were performed in SPSS 18.0 software (SPSS, Chicago, IL, USA).

\section{Results}

HOTTIP expression level

In the current study, the expression of HOTTIP was assessed by qRT-PCR. The result revealed that the expression of HOTTIP was significantly up-regulated in lung cancer samples compared with the matched noncancerous samples $(P<0.001)$ (Fig. 1).

Association between HOTTIP and clinicopathological features of lung cancer patients

In order to investigate the relationship between expression of HOTTIP and clinicopathological features of lung cancer, Chi-square test was applied in our study. The patients were divided into high expression group $(n=72)$ and low expression group $(n=60)$, according to their average expression value of HOTTIP. From the results in Table 1, we found that the elevated expression of HOTTIP was remarkable correlated with positive lymph node metastasis $(P=0.039)$ and advanced TNM stage $(P=0.007)$. However, age, gender, tumor size, differentiation and histology did not show obvious association with the expression of HOTTIP (all $P>0.05$ ).

The prognostic value of HOTTIP in patients with lung cancer

To assess the relationship between HOTTIP expression and the survival of lung cancer patients, KaplanMeier survival curves were constructed in our study. The curves suggested that the patients with low level of HOTTIP had higher survival rates than those with high level (log rank test, $P=0.011$ ) (Fig. 2). 
Cox regression analysis was applied to evaluate the prognostic significance of HOTTIP and clinical parameters in lung cancer. Analysis results demonstrated that HOTTIP was an independent prognostic factor for lung cancer patients $(\mathrm{HR}=1.916,95 \% \mathrm{Cl}=1.133-3.238, P=0.015)$ (Table 2).

Table 2

Cox regression analysis for prognosis analysis in lung cancer patients

\begin{tabular}{|c|c|c|c|c|c|c|}
\hline \multirow[t]{2}{*}{ Variables } & \multicolumn{3}{|c|}{ Univariate analysis } & \multicolumn{3}{|c|}{ Multivariate analysis } \\
\hline & HR & $95 \% \mathrm{Cl}$ & $P$ & $H R$ & $95 \% \mathrm{Cl}$ & $P$ \\
\hline $\begin{array}{l}\text { HOTTIP } \\
\text { (high vs low) }\end{array}$ & 1.916 & $\begin{array}{l}1.133- \\
3.238\end{array}$ & 0.015 & 1.916 & $\begin{array}{l}1.133- \\
3.238\end{array}$ & 0.015 \\
\hline $\begin{array}{l}\text { Age (year) } \\
(>60 \text { vs } \leq 60)\end{array}$ & 1.057 & $\begin{array}{l}0.637- \\
1.755\end{array}$ & 0.829 & - & - & - \\
\hline $\begin{array}{l}\text { Gender } \\
\text { (male vs female) }\end{array}$ & 1.171 & $\begin{array}{l}0.717- \\
1.913\end{array}$ & 0.528 & - & - & - \\
\hline $\begin{array}{l}\text { Tumor size }(\mathrm{cm}) \\
(>3 \text { vs } \leq 3)\end{array}$ & 1.026 & $\begin{array}{l}0.632- \\
1.664\end{array}$ & 0.918 & - & - & - \\
\hline $\begin{array}{l}\text { Differentiation } \\
\text { (poor vs well + moderate) }\end{array}$ & 1.196 & $\begin{array}{l}0.713^{-} \\
2.005\end{array}$ & 0.497 & - & - & - \\
\hline $\begin{array}{l}\text { Histology } \\
\text { (adenocarcinoma vs squamous cell } \\
\text { carcinoma) }\end{array}$ & 1.395 & $\begin{array}{l}0.835- \\
2.328\end{array}$ & 0.203 & - & - & - \\
\hline $\begin{array}{l}\text { Lymph node metastasis } \\
\text { (positive vs negative) }\end{array}$ & 1.280 & $\begin{array}{l}0.790- \\
2.074\end{array}$ & 0.317 & - & - & - \\
\hline $\begin{array}{l}\text { TNM stage } \\
\text { (III-IV vs I-II) }\end{array}$ & 1.065 & $\begin{array}{l}0.659- \\
1.721\end{array}$ & 0.797 & - & - & - \\
\hline
\end{tabular}

\section{Discussion}

In China, lung cancer is considered as a lethal disease due to its high mortality [21]. Despite the advances in treatments of lung cancer, the outcomes of lung cancer are still not ideal [22]. The poor prognosis may be attributed to early relapse and metastasis [7]. The mechanisms for tumor metastasis remain unclear [23]. A variety of parameters are applied to predict tumor progression of lung cancer, such as 
performance status, disease stage, and weight loss. However, the effects were far from satisfactory [24]. Thus, it is essential to explore novel biomarker for prognosis and treatment of lung cancer.

LncRNAs are a class of long non-coding RNAs, which have been reported to play regulatory roles in gene expression, ligand-receptor engagement and RNA splicing $[25,26]$. Recently studies suggested that IncRNAs were involved the initiation, response to therapy and progression of a variety of human cancers $[27,28]$. Meanwhile, some IncRNAs have ever been reported to take part in development and progression of lung cancer. XIST was an oncogenic IncRNA in NSCLC, and its elevated expression level represented shorter survival and poor prognosis [29]. LnCRNA GAS5-AS1 was down-regulated in NSCLC tissue specimens, and correlated with tumor size, TNM stage, and metastasis, suggesting its inhibitory roles in malignant development of the cancer [30]. Over-expression of IncRNA HOTAIR showed obvious link with pathological stage and lymph node metastasis of the patients that hold the potential to serve as a prognostic biomarker for lung cancer [23]. All the researches suggested that IncRNAs played pivotal roles in tumorigenesis of lung caner which might be employed as predictors for the cancer.

In this study, we investigated the expression of HOTTIP by qRT-PCR method. The results revealed that the expression of HOTTIP was significantly up-regulated in lung cancer tissue samples compared with the matched noncancerous tissue samples. Moreover, the increased HOTTIP expression showed significant associated with lymph node metastasis and TNM stage. All the data revealed that HOTTIP was an oncogenic IncRNA in lung cancer that promoted aggressive development and progression of the cancer. The conclusion was supported by the previous investigations. The study carried out by Sang et al. reported that HOTTIP was up-regulated in NSCLC tissues. Knockdown of HOTTIP could suppress cell proliferation, migration and invasion in vitro, suggesting its promoting roles in lung cancer progression [31]. However, the oncogentic mechanisms of HOTTIP in the carcinogenesis of lung cancer were far from being full elucidated. Further researches were still needed.

Given its functional roles in tumor progression, HOTTIP was proved to serve as a predictor for several cancers. Ye et al. suggested over-expression of HOTTIP could contribute to initiation and progression of gastric cancer which might be a potential prognostic biomarker for the cancer [18]. In colorectal cancer, up-regulation of HOTTIP presented poor prognosis for patients [19]. Additionally, the predictive function of HOTTIP was also reported in other types of malignancy, like osteosarcoma, tongue squamous cell carcinoma, and hepatocellular carcinoma [32-34]. Based on the previous investigations, we deduced that HOTTIP might be an effective indicator for lung cancer progression. In this study, survival curve was built based on the expression levels of HOTTIP among lung cancer patients. The curve demonstrated that lung cancer patients with low expression of HOTTIP had a longer survival than those with high expression. Cox regression analysis demonstrated that HOTTIP was an independent prognostic factor for lung cancer.

\section{Conclusions}


In conclusion, over-expression of HOTTIP plays promoting roles in malignant development and progression of lung cancer. HOTTIP may be an independent biomarker for lung cancer.

\section{List of abbreviations}

Long noncoding RNAs (IncRNAs)

quantitative real-time PCR (qRT-PCR)

non-small-cell lung cancer (NSCLC)

small-cell lung cancer (SCLC)

HOXA transcript at the distal tip (HOTTIP)

\section{Declarations}

\section{Declarations}

\section{Ethics approval and consent to participate}

This study was supported by the Ethics Committee of Cangzhou Central Hospital and also has been carried out in accordance with the World Medical Association Declaration of Helsinki.

The subjects had been informed the objective. Certainly, written consents were signed by every subject in this study.

\section{Consent for publication}

We obtaining permission from participants to publish their data.

Availability of data and materialsThe datasets used and/or analysed during the current study are available from the corresponding author on reasonable request.The authors declare that they have no competing interests.Funding Not applicable.Authors' contributions Y.Z. design of the work; X.K. the acquisition, analysis, H.W. interpretation of data; X.K. the creation of new software used in the work; Y.Z. have drafted the work or substantively revised it. All authors read and approved the final manuscript.Acknowledgements Not applicable.

\section{References}

1. Torre LA, Bray F, Siegel RL, Ferlay J, Lortet-Tieulent J, Jemal A. Global cancer statistics, 2012. Cancer J Clin. 2015;65(2):87-108.

2. Siegel R, Ma J, Zou Z, Jemal A. Cancer statistics, 2014. Cancer J Clin. 2014;64(1):9-29. 
3. McDoniels-Silvers AL, Nimri CF, Stoner GD, Lubet RA, You M. Differential gene expression in human lung adenocarcinomas and squamous cell carcinomas. Clinical cancer research: an official journal of the American Association for Cancer Research. 2002;8(4):1127-38.

4. Tuveson DA, Jacks T. Modeling human lung cancer in mice: similarities and shortcomings. Oncogene. 1999;18(38):5318-24.

5. Gong WJ, Yin JY, Li XP, Fang C, Xiao D, Zhang W, Zhou HH, Li X, Liu ZQ. Association of wellcharacterized lung cancer IncRNA polymorphisms with lung cancer susceptibility and platinumbased chemotherapy response. Tumour biology: the journal of the International Society for Oncodevelopmental Biology Medicine. 2016;37(6):8349-58.

6. Hayama M, Suzuki H, Shiroyama T, Tamiya M, Okamoto N, Tanaka A, Morishita N, Nishida T, Nishihara T, Hirashima T. Chemotherapy for patients with advanced lung cancer receiving long-term oxygen therapy. Journal of thoracic disease. 2016;8(1):116-23.

7. Liu CC, Lin JH, Hsu TW, Hsu JW, Chang JW, Su K, Hsu HS, Hung SC. Collagen XVII/laminin-5 activates epithelial-to-mesenchymal transition and is associated with poor prognosis in lung cancer. Oncotarget 2016.

8. Gibb EA, Brown CJ, Lam WL. The functional role of long non-coding RNA in human carcinomas. Mol Cancer. 2011;10:38.

9. Iguchi T, Uchi R, Nambara S, Saito T, Komatsu H, Hirata H, Ueda M, Sakimura S, Takano Y, Kurashige $\mathrm{J}$, et al. A long noncoding RNA, IncRNA-ATB, is involved in the progression and prognosis of colorectal cancer. Anticancer research. 2015;35(3):1385-8.

10. Li X, Wu Z, Fu X, Han W. Long Noncoding RNAs: Insights from Biological Features and Functions to Diseases. Medicinal research reviews. 2013;33(3):517-53.

11. Xie HW, Wu QQ, Zhu B, Chen FJ, Ji L, Li SQ, Wang CM, Tong YS, Tuo L, Wu M, et al. Long noncoding RNA SPRY4-IT1 is upregulated in esophageal squamous cell carcinoma and associated with poor prognosis. Tumour biology: the journal of the International Society for Oncodevelopmental Biology Medicine. 2014;35(8):7743-54.

12. He Y, Meng XM, Huang C, Wu BM, Zhang L, Lv XW, Li J. Long noncoding RNAs: Novel insights into hepatocelluar carcinoma. Cancer letters. 2014;344(1):20-7.

13. Gan L, Xu M, Zhang Y, Zhang X, Guo W. Focusing on long noncoding RNA dysregulation in gastric cancer. Tumour biology: the journal of the International Society for Oncodevelopmental Biology Medicine. 2015;36(1):129-41.

14. Zhou M, Guo M, He D, Wang X, Cui Y, Yang H, Hao D, Sun J. A potential signature of eight long noncoding RNAs predicts survival in patients with non-small cell lung cancer. Journal of translational medicine. 2015;13:231.

15. Ricciuti B, Mencaroni C, Paglialunga L, Paciullo F, Crino L, Chiari R, Metro G. Long noncoding RNAs: new insights into non-small cell lung cancer biology, diagnosis and therapy. Med Oncol. 2016;33(2):18.

16. Burgess DJ. Non-coding RNA: HOTTIP goes the distance. Nature reviews Genetics. 2011;12(5):300. 
17. Zhang SR, Yang JK, Xie JK, Zhao LC. Long noncoding RNA HOTTIP contributes to the progression of prostate cancer by regulating HOXA13. Cell Mol Biol (Noisy-le-grand). 2016;62(3):84-8.

18. Ye H, Liu K, Qian K. Overexpression of long noncoding RNA HOTTIP promotes tumor invasion and predicts poor prognosis in gastric cancer. OncoTargets therapy. 2016;9:2081-8.

19. Ren YK, Xiao Y, Wan XB, Zhao YZ, Li J, Li Y, Han GS, Chen XB, Zou QY, Wang GC, et al. Association of long non-coding RNA HOTTIP with progression and prognosis in colorectal cancer. Int J Clin Exp Pathol. 2015;8(9):11458-63.

20. Deng HP, Chen L, Fan T, Zhang B, Xu Y, Geng Q. Long non-coding RNA HOTTIP promotes tumor growth and inhibits cell apoptosis in lung cancer. Cell Mol Biol (Noisy-le-grand). 2015;61(4):34-40.

21. Zhi XY, Zou XN, Hu M, Jiang Y, Jia MM, Yang GH. Increased lung cancer mortality rates in the Chinese population from 1973-1975 to 2004-2005: An adverse health effect from exposure to smoking. Cancer. 2015;121(Suppl 17):3107-12.

22. Muralidaran A, Detterbeck FC, Boffa DJ, Wang Z, Kim AW. Long-term survival after lung resection for non-small cell lung cancer with circulatory bypass: a systematic review. J Thorac Cardiovasc Surg. 2011;142(5):1137-42.

23. Liu XH, Liu ZL, Sun M, Liu J, Wang ZX, De W. The long non-coding RNA HOTAIR indicates a poor prognosis and promotes metastasis in non-small cell lung cancer. BMC Cancer. 2013;13:464.

24. Gu X, Tian T, Zhang B, Liu Y, Yuan C, Shao L, Guo Y, Fan K. Elevated plasma interleukin-35 levels predict poor prognosis in patients with non-small cell lung cancer. Tumour biology: the journal of the International Society for Oncodevelopmental Biology Medicine. 2015;36(4):2651-6.

25. Wang KC, Chang HY. Molecular mechanisms of long noncoding RNAs. Molecular cell. 2011;43(6):904-14.

26. Booton R, Lindsay MA. Emerging role of MicroRNAs and long noncoding RNAs in respiratory disease. Chest. 2014;146(1):193-204.

27. Zhang H, Chen Z, Wang X, Huang Z, He Z, Chen Y. Long non-coding RNA: a new player in cancer. J Hematol Oncol. 2013;6:37.

28. Prensner JR, Chinnaiyan AM. The emergence of IncRNAs in cancer biology. Cancer discovery. 2011;1(5):391-407.

29. Fang J, Sun CC, Gong C. Long noncoding RNA XIST acts as an oncogene in non-small cell lung cancer by epigenetically repressing KLF2 expression. Biochem Biophys Res Commun. 2016;478(2):811-7.

30. Wu Y, Lyu H, Liu H, Shi X, Song Y, Liu B. Downregulation of the long noncoding RNA GAS5-AS1 contributes to tumor metastasis in non-small cell lung cancer. Scientific reports. 2016;6:31093.

31. Sang Y, Zhou F, Wang D, Bi X, Liu X, Hao Z, Li Q, Zhang W. Up-regulation of long non-coding HOTTIP functions as an oncogene by regulating HOXA13 in non-small cell lung cancer. American journal of translational research. 2016;8(5):2022-32. 
32. Li F, Cao L, Hang D, Wang F, Wang Q. Long non-coding RNA HOTTIP is up-regulated and associated with poor prognosis in patients with osteosarcoma. Int J Clin Exp Pathol. 2015;8(9):11414-20.

33. Zhang H, Zhao L, Wang YX, Xi M, Liu SL, Luo LL. Long non-coding RNA HOTTIP is correlated with progression and prognosis in tongue squamous cell carcinoma. Tumour biology: the journal of the International Society for Oncodevelopmental Biology Medicine. 2015;36(11):8805-9.

34. Quagliata L, Matter MS, Piscuoglio S, Arabi L, Ruiz C, Procino A, Kovac M, Moretti F, Makowska Z, Boldanova T, et al. Long noncoding RNA HOTTIP/HOXA13 expression is associated with disease progression and predicts outcome in hepatocellular carcinoma patients. Hepatology. 2014;59(3):911-23.

\section{Figures}

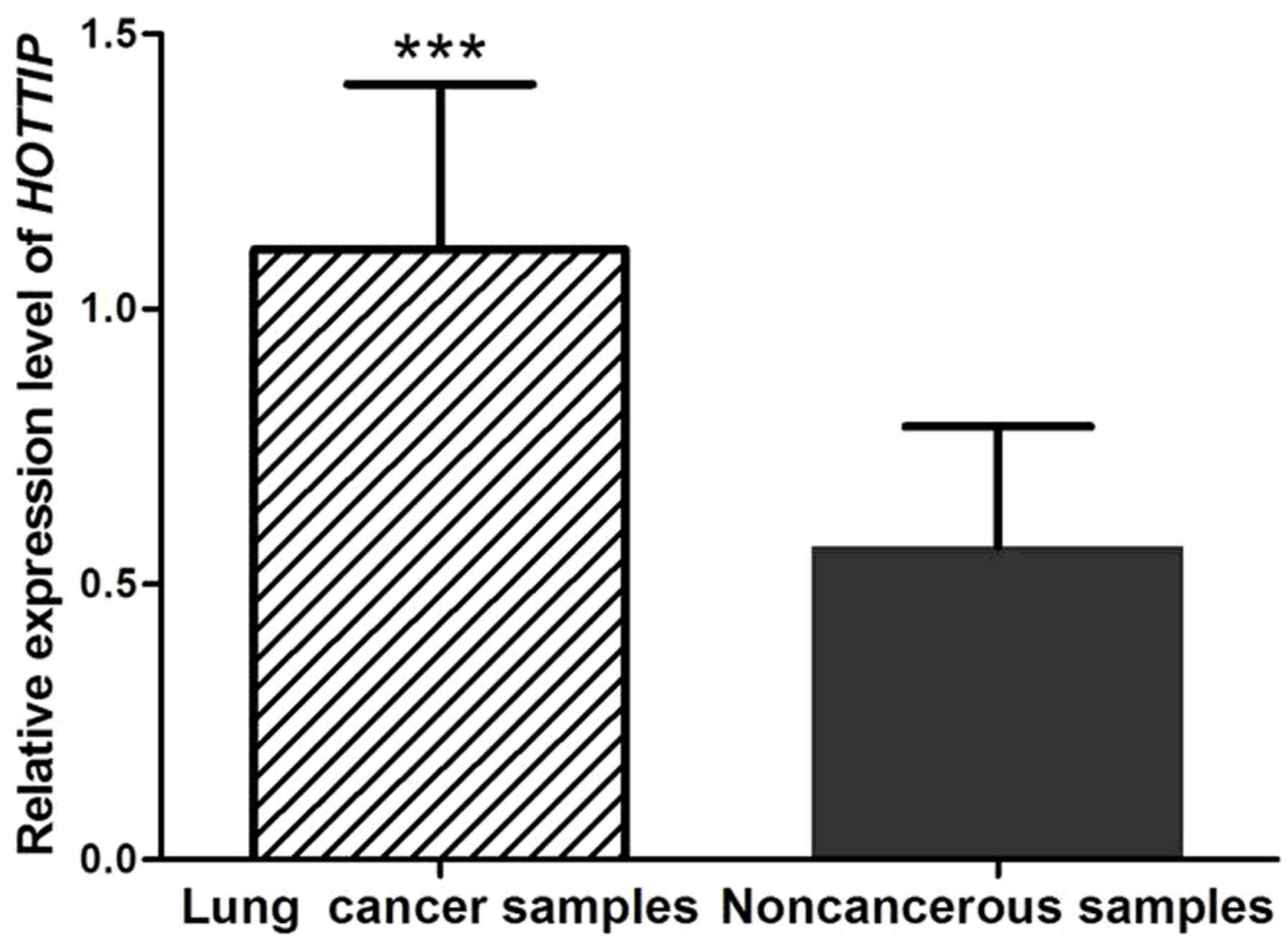

Figure 1

The expression of HOTTIP in lung cancer tissue samples and paired noncancerous samples. HOTTIP expression level was up-regulated in lung cancer tissues, compared with non-cancerous tissues. *ᄎ*: suggested $\mathrm{P}<0.001$. 


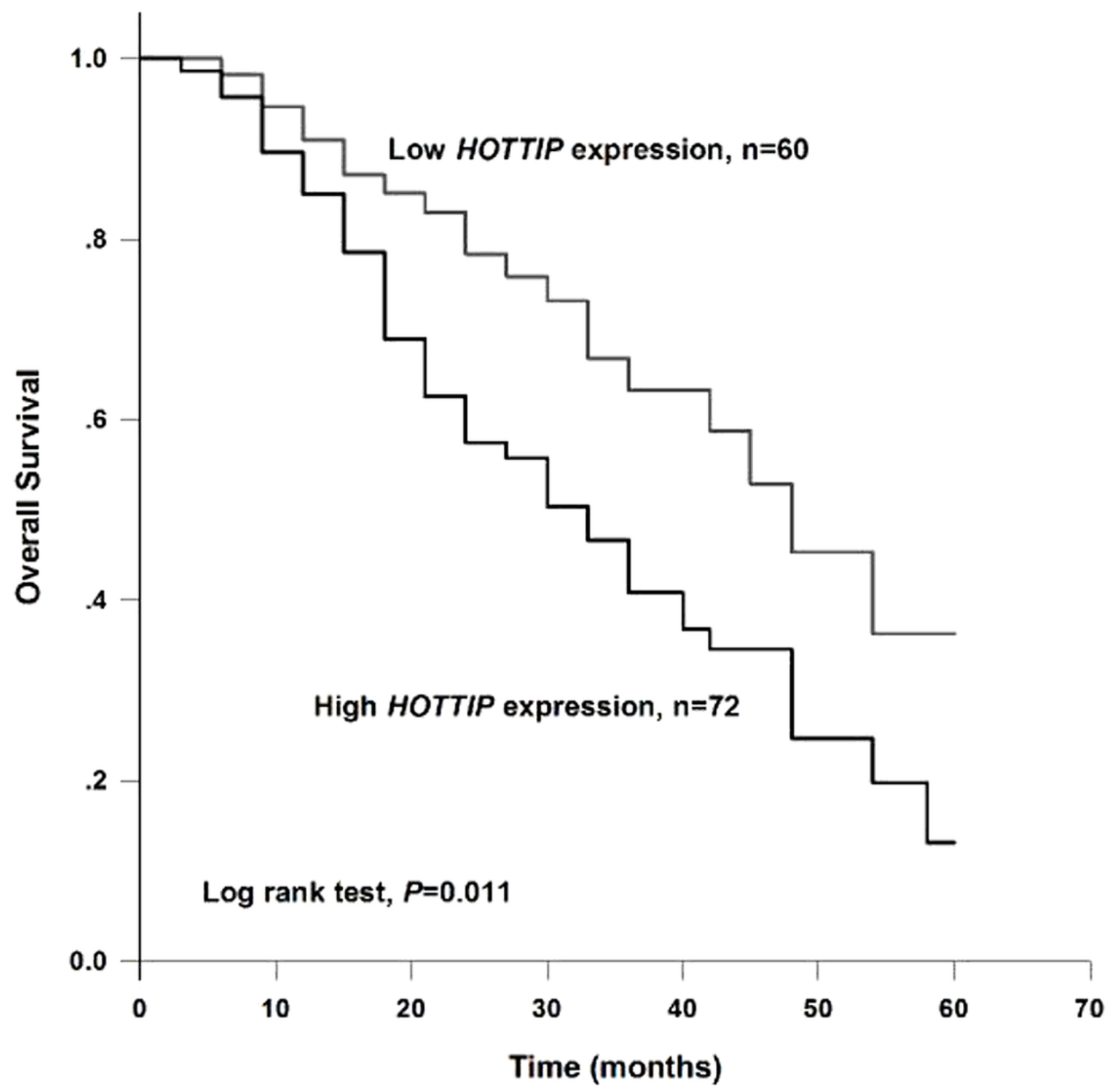

Figure 2

The Kaplan-Meier survival curves for lung cancer patients based on their expression of HOTTIP. The curve demonstrated that patients with high expression of HOTTIP had a shorted overall survival than those with low expression (log rank test, $\mathrm{P}=0.011$ ). 